\title{
Remote Oxidative Activation of a [Cp*Rh] Monohydride
}

\author{
Emily A. Boyd, ${ }^{[a, t, \#]}$ Julie A. Hopkins Leseberg, ${ }^{[a, \#]}$ Emma L. Cosner, ${ }^{[a, \#]}$ Davide Lionetti, ${ }^{[a, *]}$ Wade \\ C. Henke, ${ }^{[a]}$ Victor W. Day, ${ }^{[a]}$ and James D. Blakemore ${ }^{\star[a]}$
}

[a] E.A. Boyd, J.A. Hopkins Leseberg, E. Cosner, D. Lionetti, W.C. Henke, V. W. Day, and

Prof. J. D. Blakemore

Department of Chemistry, University of Kansas

1567 Irving Hill Road, Lawrence, Kansas 66045, United States

$\dagger$ Current Address: Division of Chemistry and Chemical Engineering, California Institute of

Technology

Pasadena, California 91125, United States

$\$ \quad$ Current Address: Department of Chemistry, Franklin \& Marshall College

P.O. Box 3003, Lancaster, Pennsylvania 17604, United States.

\# These authors contributed equally.

* To whom correspondence should be addressed. E-mail: blakemore@ku.edu.

\begin{abstract}
Half-sandwich rhodium monohydrides are often proposed as intermediates in catalysis, but little is known regarding the redox-induced reactivity accessible to these species. Here, the $x^{2}-$ bis-diphenylphosphinoferrocene (dppf) ligand has been used to explore the reactivity that can be induced when a $\left[\mathrm{Cp}^{*} \mathrm{Rh}\right]$ monohydride undergoes remote (dppf-centered) oxidation by $1 \mathrm{e}^{-}$. Chemical and electrochemical studies showed that one-electron redox chemistry is accessible to $\mathrm{Cp} \mathrm{p}^{*} \mathrm{Rh}(\mathrm{dppf})$, including a unique quasi-reversible $\mathrm{Rh}^{\mathrm{II} / \mathrm{I}}$ process at $-0.96 \mathrm{~V}$ vs. ferrocenium/ferrocene $\left(\mathrm{Fc}^{+/ 0}\right)$. This redox manifold was confirmed by isolation of an uncommon $\mathrm{Rh}$ (II) species that was characterized by EPR spectroscopy. Protonation of Cp*Rh(dppf) with anilinium triflate yielded an isolable and inert monohydride, and this species was found to undergo a quasireversible electrochemical oxidation at $+0.41 \mathrm{~V} \mathrm{vs} \mathrm{Fc}^{+/ 0}$ that corresponds to iron-centered oxidation in the dppf backbone. Thermochemical analysis predicts that this dppf-centered oxidation drives a dramatic increase in acidity of the $\mathrm{Rh}-\mathrm{H}$ moiety by $23 \mathrm{p} K_{\mathrm{a}}$ units, a reactivity pattern confirmed by in situ ${ }^{1} \mathrm{H}$ NMR studies. Taken together, these results show that remote oxidation can effectively induce $\mathrm{M}-\mathrm{H}$ activation and suggest that ligand-centered redox activity could be an attractive feature for design of new systems relying on hydride intermediates.
\end{abstract}

\section{Introduction}

A primary strength of transition metal catalysts lies in their ability to cycle between two or more oxidation states, thereby facilitating electron transfer during transformations of various substrates. Traditionally, ligands in catalytic metal complexes were viewed as sources of structural support or as sites for modulation of the properties of the metal center via synthesis-driven tuning of steric or electronic effects. However, a large body of work has explored ligand "non-innocence", or the ability of ligands to actively participate in electron transfer and/or bond-making and breaking steps in catalysis. ${ }^{[1]}$ The most common class of non-innocent ligands is composed of redox-active ligands, which can undergo oxidation or reduction with no change to the formal 
oxidation state at the metal centers to which they are bound, thereby complementing metal-based electron transfer chemistry. ${ }^{[2]}$

Our group has recently been studying the role that redox-active diimine-type ligands can play in modulating the reactivity and overpotential of a family of notable hydrogen-evolution catalysts of the type $\left[\mathrm{Cp}^{*} \mathrm{Rh}(\text { diimine })(\mathrm{Cl})\right]^{+} \cdot{ }^{[3]}$ These species have attracted significant attention over the years for their ease of preparation, robust activity, and applicability to related reductive reactions, including $\mathrm{NAD}^{+}$to NADH conversion in bioelectrochemical cells. ${ }^{[4]}$ The rhodium(I) complex $\mathrm{Cp}^{*} \mathrm{Rh}$ (phen) (where phen is 1,10-phenanthroline), for example, exhibits extensive delocalization of electron density onto the redox-active phen ligand, stabilizing the electron-rich metal center and facilitating catalysis at a modest overpotential.$^{[5]}$ Use of diimine ligands such as phen also promotes generation of uncommon $\left[\eta^{4}-\mathrm{Cp}^{*} \mathrm{H}\right]$ complexes upon protonation of reduced precursors, rather than the more expected monohydrides, a phenomenon that has generated renewed interest in this area in recent years. ${ }^{[6]}$

On the other hand, we have shown that bidentate phosphine ligands stabilize [Cp* Rh] hydride complexes, and that these complexes display unique reductive electrochemical properties. Reduction of $\left[\mathrm{Cp}^{*} \mathrm{Rh}(\mathrm{dppb}) \mathrm{H}\right]^{+}(\mathrm{dppb}=$ diphenylphosphino benzene $)$ occurs at $-2.35 \mathrm{~V}$ vs. $\mathrm{Fc}^{+/ 0},{ }^{[7]}$ an event that is likely metal-centered in nature and results in $\mathrm{Rh}-\mathrm{H}$ cleavage concomitant with $\mathrm{H}_{2}$ evolution. Conversely, the analogous $[\mathrm{Cp} * \mathrm{Rh}(\mathrm{pqn}) \mathrm{H}]^{+}$supported by the hybrid 8(diphenylphosphino)quinoline ligand (pqn) undergoes reduction at ca. $600 \mathrm{mV}$ more positive than the dppb-supported hydride. ${ }^{[8]}$ This anodic shift can be attributed to involvement of the redox-noninnocent pqn ligand in the reduction process. Considering these results, bidentate ligands can be reliably concluded to play an important role in governing the reductive redox chemistry of $[\mathrm{Cp} * \mathrm{Rh}]$ complexes and their corresponding protonated forms.$^{[9]}$

Significantly less has been reported regarding the oxidative redox chemistry of [Cp* Rh] hydride complexes. Of relevance here, electrochemical studies of $[\mathrm{Cp} * \mathrm{Rh}(\mathrm{dppb}) \mathrm{H}]^{+}$have revealed that this complex can undergo irreversible oxidation at a relatively positive peak potential of ca. $+990 \mathrm{mV}$ vs. $\mathrm{Fc}^{+/ 0} \cdot{ }^{[7]}$ In line with the irreversible nature of the voltammetry in this case, thermochemical analysis suggests that this oxidation results in acidification of the $\mathrm{Rh}-\mathrm{H}$ unit in the complex by as much as 30 orders of magnitude. ${ }^{[10]}$ Unfortunately, the irreversible nature of this oxidation event precludes more precise understanding of the process(es) involved in the followup chemical reactivity and limits precise quantification of the thermochemical properties of the system. In light of the importance of the redox chemistry of metal hydride complexes, we envisioned that development of a model [Cp* Rh] hydride system which displays more reversible oxidative electrochemistry could provide insight into the manifold of reactivity promoted by oxidation, a topic that has received less attention than it deserves. Thus, we targeted use of the diphosphine ligand bis(diphenylphosphino) ferrocene (dppf) with the hypothesis that the oneelectron oxidation accessible to the ferrocenyl moiety in the dppf backbone could provide anodic access to two forms of a [Cp*Rh] hydride. ${ }^{[11,12]}$ Such a situation could enable remote tuning of the ligand field and hydride properties via redox cycling of the iron center in dppf.

Here, we report results on a series of $[\mathrm{Cp} * \mathrm{Rh}]$ complexes ligated by dppf (see Scheme 1). We find that two-electron reduction of $\left[\mathrm{Cp}^{*} \mathrm{Rh}^{\mathrm{III}}(\mathrm{dppf}) \mathrm{Cl}\right]^{+}(\mathbf{1})$ cleanly yields an analogous rhodium(I) complex (2); unusually, reoxidation of $\mathbf{2}$ in the absence of $\mathrm{Cl}^{-}$occurs in distinct $1 \mathrm{e}^{-}$steps, such that chemical re-oxidation of $\mathbf{2}$ by $1 \mathrm{e}^{-}$could be carried out to generate a paramagnetic complex with an X-band electron paramagnetic resonance (EPR) spectrum consistent with an $S=1 / 2 \mathrm{Rh}^{\mathrm{II}}$ complex. Protonation of 2 returns an inert [Cp* Rh] monohydride (4), the structure of which was confirmed with single-crystal X-ray diffraction analysis (XRD). Unlike the $\left[\mathrm{Cp}^{*} \mathrm{Rh}(\mathrm{dppb}) \mathrm{H}\right]^{+}$ 
complex, electrochemical oxidation of $\mathbf{4}$ is quasireversible and occurs at a modest potential of $+0.41 \mathrm{~V}$ vs. $\mathrm{Fc}^{+/ 0}$, attributable to iron(III)/iron(II) redox cycling. The quasi-reversible nature of the oxidation of 4 was used to determine precise thermochemical values, among these a prediction that oxidation of the dppf moiety increases the acidity of the rhodium-hydride by $23 \mathrm{p} K_{\mathrm{a}}$ units. An experiment with the oxidant $\left[\mathrm{Ru}(\mathrm{bpy})_{3}\right]^{3+}$ monitored by ${ }^{1} \mathrm{H}$ NMR confirmed the acidification and resultant cleavage of the $\mathrm{Rh}-\mathrm{H}$ bond. Taken together, these results reveal the power of remote ligand-centered oxidation on influencing the reactivity of a metal hydride species.

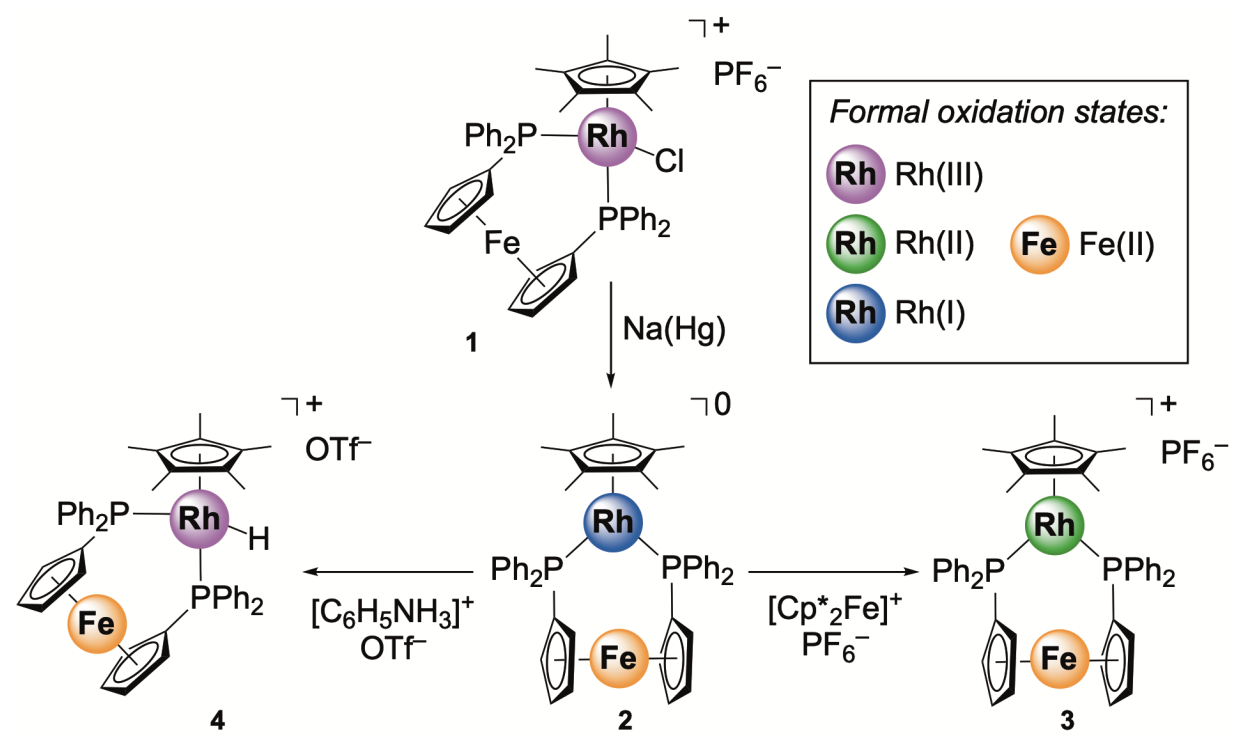

Scheme 1. Summary of the preparation and chemical reactivity of [Cp* $\mathrm{Ch}]$ complexes supported by the dppf ligand.

\section{Results and Discussion}

The synthesis, spectroscopic characterization, and X-ray diffraction structure of the $[\mathrm{Cp} * \mathrm{Rh}(\mathrm{dppf}) \mathrm{Cl}]^{+}$(1; see Scheme 1) have been previously reported. ${ }^{[13]}$ However, the electrochemical properties of $\mathbf{1}$ were not investigated in the prior work. Cyclic voltammetric investigation of $\mathbf{1}$ at oxidizing potentials reveals a single quasi-reversible couple centered at +0.38 $\mathrm{V}$ vs. the ferrocenium/ferrocene couple (denoted hereafter as $\mathrm{Fc}^{+/ 0}$ ) with a peak-to-peak separation $\left(\Delta E_{\mathrm{p}}\right)$ of $158 \mathrm{mV}$ typical of $1 \mathrm{e}^{-}$couples in THF (see Figure 1 ). This couple can be assigned to $\mathrm{Fe}^{\mathrm{III} / \mathrm{II}}$ redox cycling within the ferrocenyl moiety of the dppf ligand. ${ }^{[14]}$

Scanning cathodically from a potential of ca. $-0.6 \mathrm{~V}$ vs. $\mathrm{Fc}^{+/ 0}$ reveals that 1 undergoes a reduction and coupled oxidation at $E_{1 / 2}=-1.12 \mathrm{~V} \mathrm{vs}$. $\mathrm{Fc}^{+/ 0}$ (Figure 1) for which there is approximately double the cathodic current density as compared to the couple assigned as $\mathrm{Fe}^{\mathrm{III} / \mathrm{II}}\left(i_{\mathrm{p}, \mathrm{c}}\left(\mathrm{Fe}^{\mathrm{III} / \mathrm{II}}\right)=-0.096 \mathrm{~mA}\right.$ $\mathrm{cm}^{-1}, i_{\mathrm{p}, \mathrm{c}}=-0.203 \mathrm{~mA} \mathrm{~cm}^{-1}$ ). This feature is attributable to $2 \mathrm{e}^{-}$reduction of the $\mathrm{Rh}$ center. Scanrate-dependent studies of the $\mathrm{Rh}^{\mathrm{III} / \mathrm{I}}$ and $\mathrm{Fe}^{\mathrm{III} / \mathrm{II}}$ couples verify that all species present in the cyclic voltammetry of $\mathbf{1}$ are freely diffusing in solution and soluble in THF (see SI, Figure S27 and S28). Preliminary interrogation of $\mathbf{1}$ in $\mathrm{CH}_{3} \mathrm{CN}$ indicated that there is a non-linear trend between peak currents of the $\mathrm{Rh}^{\mathrm{II} / \mathrm{I}}$ and $\mathrm{Fe}^{\mathrm{III} / \mathrm{II}}$ couples with the square root of scan rate, indicating all species are 
not freely diffusing, an observation attributable to insolubility of the corresponding $\mathrm{Rh}^{\mathrm{I}} \mathrm{species}$ in $\mathrm{CH}_{3} \mathrm{CN}$; therefore, all electrochemical experiments with [Cp* Rh(dppf)] were performed in THF going forward. Complex 1 likely undergoes an ECE-type electrochemical reduction mechanism with potential inversion ${ }^{[15]}$ similar to other [Cp* $\left.\mathrm{Rh}\right]$ complexes supported by bidentate chelating ligands. In these situations, $1 \mathrm{e}^{-}$reduction is followed by loss of the chloride ligand, generating a transient $17 \mathrm{e}^{-}$, five-coordinate species with a reduction potential equal to or more positive than that of the initial $18 \mathrm{e}^{-}$chloride-bound complex $1 .^{[8]}$

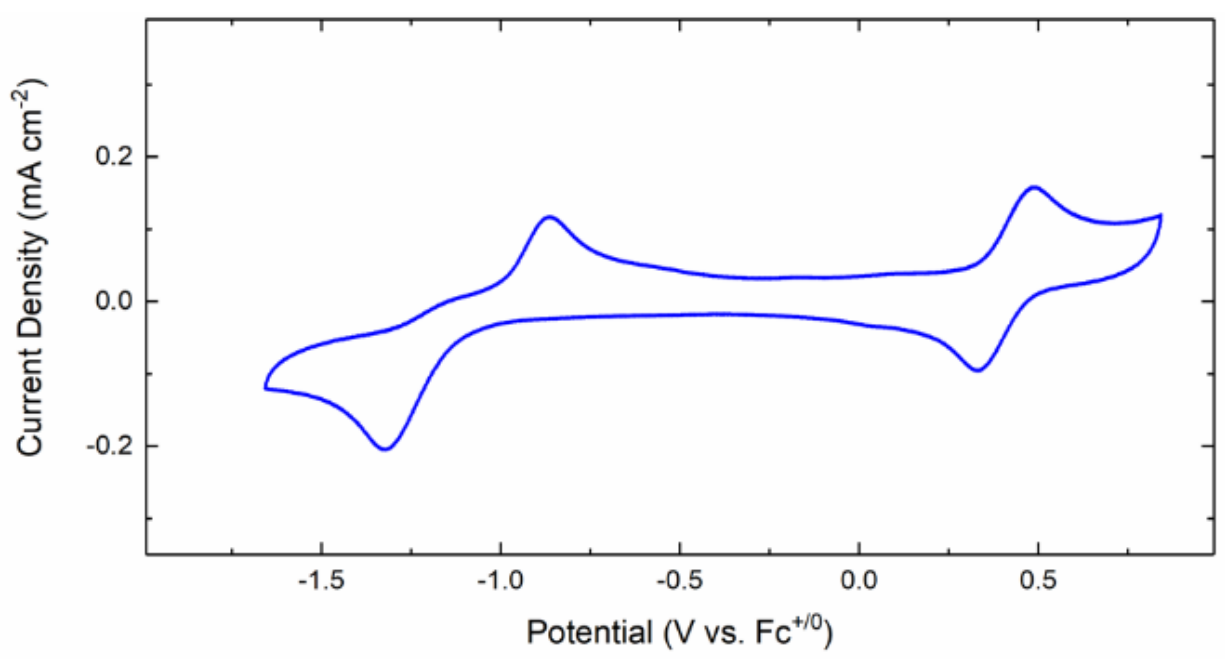

Figure 1. Cyclic voltammetry of $1(2 \mathrm{mM})$. Conditions: electrolyte, $0.1 \mathrm{M} \mathrm{TBAPF}_{6}$ in THF; scan rate, $100 \mathrm{mV} / \mathrm{s}$; working electrode, highly oriented pyrolytic graphite (HOPG). The initial potential of the voltammogram of was at ca. $-0.6 \mathrm{~V}$ vs. $\mathrm{Fc}^{+/ 0}$.

Consistent with the assignment of the quasireversible redox event centered at $-1.12 \mathrm{~V}$ vs. $\mathrm{Fc}^{+/ 0}$ as a $2 \mathrm{e}^{-} \mathrm{Rh}^{\mathrm{III} / \mathrm{I}}$ couple, reduction of $\mathbf{1}$ with excess sodium amalgam (10 equiv.) in THF and extraction with toluene yielded the reddish-brown diamagnetic solid assigned as Cp*Rh(dppf) (2; see Scheme 1). Characterization data for $\mathbf{2}$ are given in the Supporting Information, see Figure S2S4). Cyclic voltametric analysis of 2 revealed a quasi-reversible redox event centered at $-0.96 \mathrm{~V}$ vs. $\mathrm{Fc}^{+/ 0}$ with a peak-to-peak separation of $171 \mathrm{mV}$. The anodic and cathodic currents associated with this wave depend linearly on the square root of scan rate, indicating the oxidized and reduced forms are freely diffusing in solution (see SI, Figures S29 and S30). The anodic peak associated with the couple at $-0.96 \mathrm{~V}$ vs. $\mathrm{Fc}^{+/ 0}$ coincides with the anodic wave of the $\mathrm{Rh}^{\mathrm{II} / \mathrm{I}}$ couple in 1 (see Figure 2), suggesting that $\mathbf{2}$ is generated in situ by electrochemical $2 \mathrm{e}^{-}$reduction of $\mathbf{1}$. However, in these $\mathrm{CV}$ studies using isolated $\mathbf{2}$, scanning further positive reveals an irreversible anodic feature with $E_{\mathrm{p}, \mathrm{a}}=-0.01 \mathrm{~V}$ vs. $\mathrm{Fc}^{+/ 0}$; this is followed by another quasireversible redox couple centered at $+0.51 \mathrm{~V}$ vs. $\mathrm{Fc}^{+/ 0}$, which can be reasonably assigned as the $\mathrm{Fe}^{\mathrm{III} / \mathrm{II}}$ couple of 2 . The potential of the $\mathrm{Fe}^{\mathrm{III} / \mathrm{II}}$ couple observed for $\mathbf{2}$ is approximately $130 \mathrm{mV}$ positive of the $\mathrm{Fe}^{\mathrm{III} / \mathrm{II}}$ reduction potential for 1. We attribute this shift to the absence of chloride anions in cyclic voltammetry of 2 . Thus, while presence of the X-type chloride ligand in $\mathbf{1}$ mitigates charge buildup upon oxidation, the lack of available chloride anions in the cyclic voltammetry of $\mathbf{2}$ prevents this stabilization and shifts the $\mathrm{Fe}^{\mathrm{III} / \mathrm{II}}$ potential positive. 


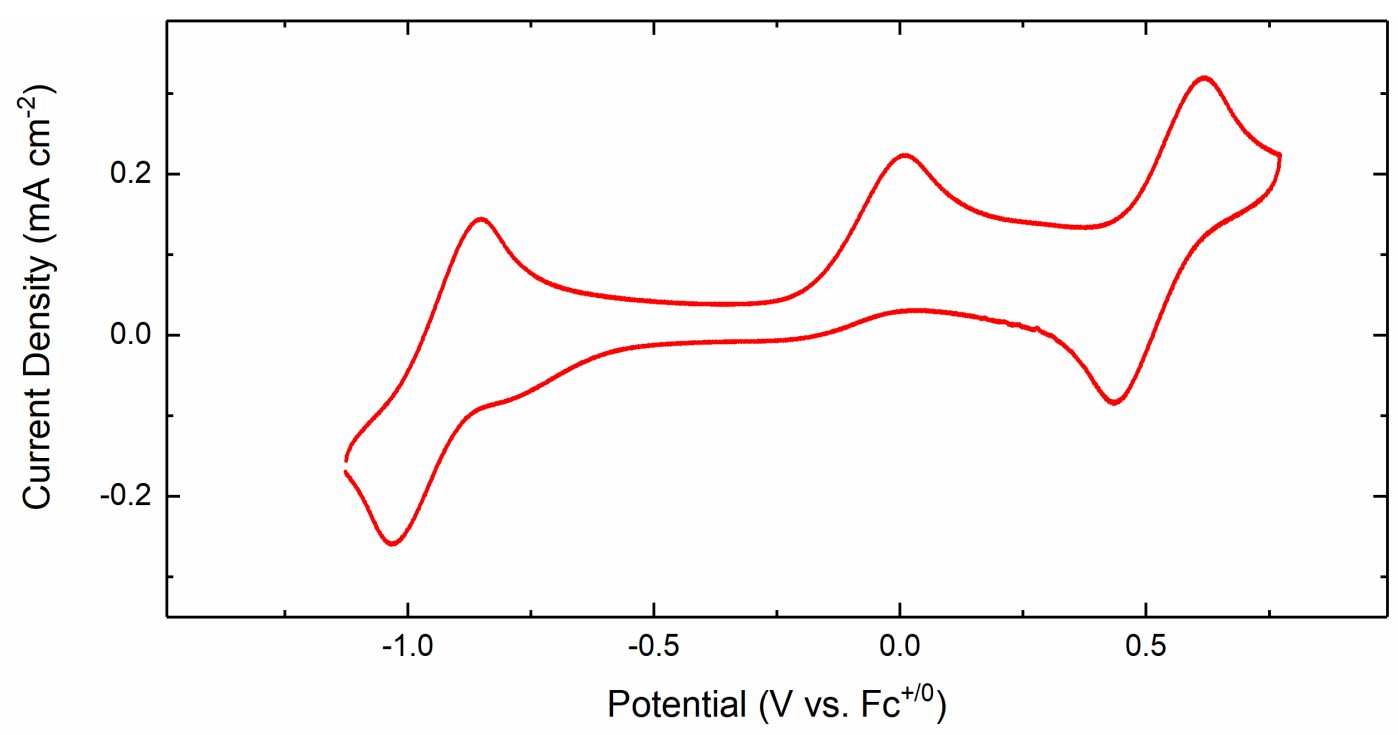

Figure 2. Cyclic voltammetry of $2(2 \mathrm{mM})$. Conditions: electrolyte, $0.1 \mathrm{M} \mathrm{TBAPF}_{6}$ in THF; scan rate, $100 \mathrm{mV} / \mathrm{s}$; working electrode, HOPG. The initial potential of the voltammogram of is at ca. $-1.20 \mathrm{~V}$ vs. $\mathrm{Fc}^{+/ 0}$.

Given the assignment of the more-positive oxidation event as a $1 \mathrm{e}^{-}$ferrocenyl-centered couple, and the similarity of the peak current densities involved, the anodic wave at ca. $-0.96 \mathrm{~V}$ can be attributed to oxidation of the $\mathrm{Rh}^{\mathrm{I}}$ center in a $1 \mathrm{e}^{-}$process (see the summary of redox chemistry for 2 in Scheme 2). This $1 \mathrm{e}^{-}$chemistry contrasts with the more common $2 \mathrm{e}^{-}$, ECE-type processes that are typical of $[\mathrm{Cp} * \mathrm{Rh}]$ systems supported by bidentate diimine ${ }^{[16]}$ or diphosphine ${ }^{[7]}$ ligands. Within this paradigm, the oxidation event at $-0.96 \mathrm{~V}$ represents oxidation of $\mathrm{Rh}^{\mathrm{I}}$ in $\mathbf{2}$ to the $\mathrm{Rh}^{\mathrm{II}}$ oxidation state; further, the oxidative wave near $0 \mathrm{~V}$ should correspond to the oxidation of $\mathrm{Rh}^{\mathrm{II}}$ to $\mathrm{Rh}^{\mathrm{III}}$.

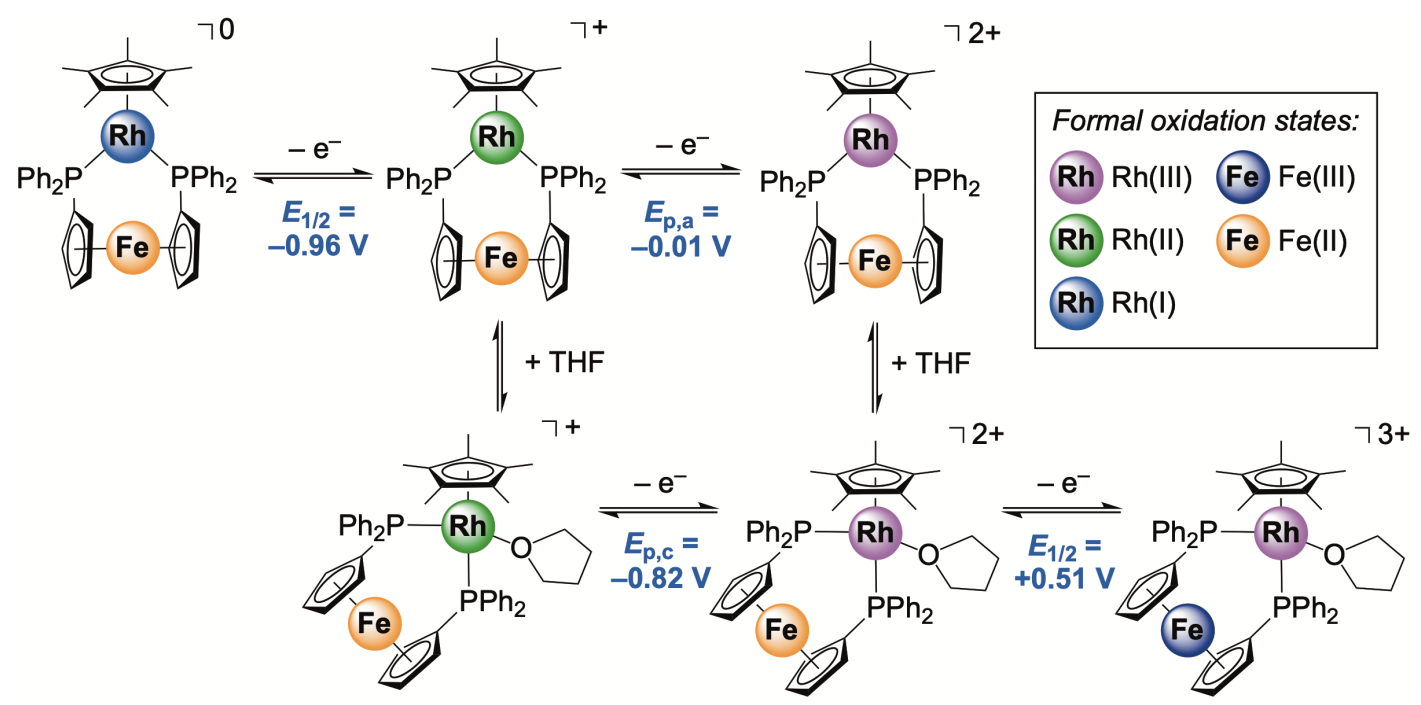

Scheme 2. Summary of the proposed chemical structures and accessible oxidation states for the chemically prepared complex 2 . 
This assignment was substantiated by parallel chemical work. The reduction potential of decamethylferrocenium $\left(\left[\mathrm{Cp}^{*}{ }_{2} \mathrm{Fe}\right]^{+}\right.$) falls well positive of the $\mathrm{Rh}^{\mathrm{II} / \mathrm{I}}$ couple of $\mathbf{2}$, thus treatment of $\mathbf{2}$ with $\left[\mathrm{Cp}^{*}{ }_{2} \mathrm{Fe}\right]^{+}$should result in removal of a single electron from the $\mathrm{Rh}$ complex. Indeed, addition of one equivalent of $\left[\mathrm{Cp}^{*}{ }_{2} \mathrm{Fe}\right]^{+} \mathrm{PF}_{6}{ }^{-}\left(E_{1 / 2}=-0.59 \mathrm{~V}\right.$ vs. $\left.\mathrm{Fc}^{+/ 0}\right)$ to 2 in THF leads to a rapid color change from reddish-brown to dark green. ${ }^{[17]}$ Extraction with hexanes after removal of volatiles yielded decamethylferrocene (ca. 95\% yield by ${ }^{1} \mathrm{H}$ NMR), indicating that electron transfer to $\left[\mathrm{Cp}_{2}{ }_{2} \mathrm{Fe}\right]^{+}$had occurred. Subsequent washing of the hexanes-insoluble material with $\mathrm{Et}_{2} \mathrm{O}$ and toluene followed by extraction with THF yielded a dark green solid that returned no interpretable resonances in ${ }^{1} \mathrm{H}$ NMR (see SI, Figure S5). This profile is indicative of formation of a paramagnetic species, expected to be the product of $1 \mathrm{e}^{-}$oxidation of $\mathbf{2}$, and based on its electrochemical properties, this compound was assigned as $\left[\mathrm{Cp}^{*} \mathrm{Rh}(\mathrm{dppf})\right] \mathrm{PF}_{6}(\mathbf{3}$, see Scheme 1).

Support for the identity of $\mathbf{3}$ comes from its X-band EPR spectrum (see Figure 3), which reveals a distinctive set of features with axial symmetry $\left(g_{1}=2.18, g_{2}=2.03\right)$, confirming that oxidation of 2 with $\left[\mathrm{Cp}_{2}{ }_{2} \mathrm{Fe}\right]^{+}$generates a paramagnetic species. ${ }^{[18]}$ The relatively small $g$ anisotropy $(\Delta g=0.15)$ of the signal suggests that this oxidation is Rh-centered, as oxidation at the Fe center of the dppf ligand would generate a ferrocenium-type system characterized by much broader signals (e.g., for the ferrocenium ion, $\Delta g=3.08$, with $g_{1}=4.36$ and $g_{2}=1.28$ ). ${ }^{[19]}$ The $g$ values observed for $\mathbf{3}$ are also consistent with literature values for rhodium(II) systems. ${ }^{[18,20]}$ We therefore assign the product of oxidation of 2 as $\left[\mathrm{Cp}^{*} \mathrm{Rh}^{\mathrm{II}}(\mathrm{dppf})\right]^{+} \mathrm{PF}_{6}{ }^{-}$, a formulation which supports the interpretation of the CV data given above for 2 . THF binding is very likely upon oxidation of 2 , suggesting that the $\mathrm{Rh}$ (II) and especially $\mathrm{Rh}$ (III) forms of the compound are ligated by THF; THF binding to Rh(III) allows the complex to attain an $18 \mathrm{e}^{-}$configuration.

Within this paradigm, the anodic process at ca. $0 \mathrm{~V}$ vs. $\mathrm{Fc}^{+/ 0}$ corresponds to $1 \mathrm{e}^{-}$oxidation of $\mathrm{Rh}^{\mathrm{II}}$ to $\mathrm{Rh}^{\mathrm{III}}{ }^{[21]}$ This anodic feature is paired with a broad reductive feature at $-0.82 \mathrm{~V}$; these together are assigned as the $\mathrm{Rh}^{\mathrm{III} / I I}$ waves in this system. This cathodic feature is notably positive of the $\mathrm{Rh}^{\mathrm{II} / \mathrm{I}}$ cathodic feature with $E_{\mathrm{p}, \mathrm{c}} \approx-1.05 \mathrm{~V}$ (see Figure 2), and is only observed in voltammetry after traversing the paired anodic wave near $0 \mathrm{~V}$. Consistent with this interpretation, cycling of a solution containing the $\mathrm{Rh}^{\mathrm{I}}$ complex 2 up to only $-0.55 \mathrm{~V}$ reveals no evidence for the $\mathrm{Rh}^{\mathrm{III}}$ to $\mathrm{Rh}^{\mathrm{II}}$ reduction at $-0.82 \mathrm{~V}$ (see SI, Figure S29). Therefore, we conclude that the $\mathrm{Rh}^{\mathrm{III}}$ species is produced in the electrochemical cell only upon oxidation of the $\mathrm{Rh}^{\mathrm{II}}$ form of the compound at $0 \mathrm{~V}$. 


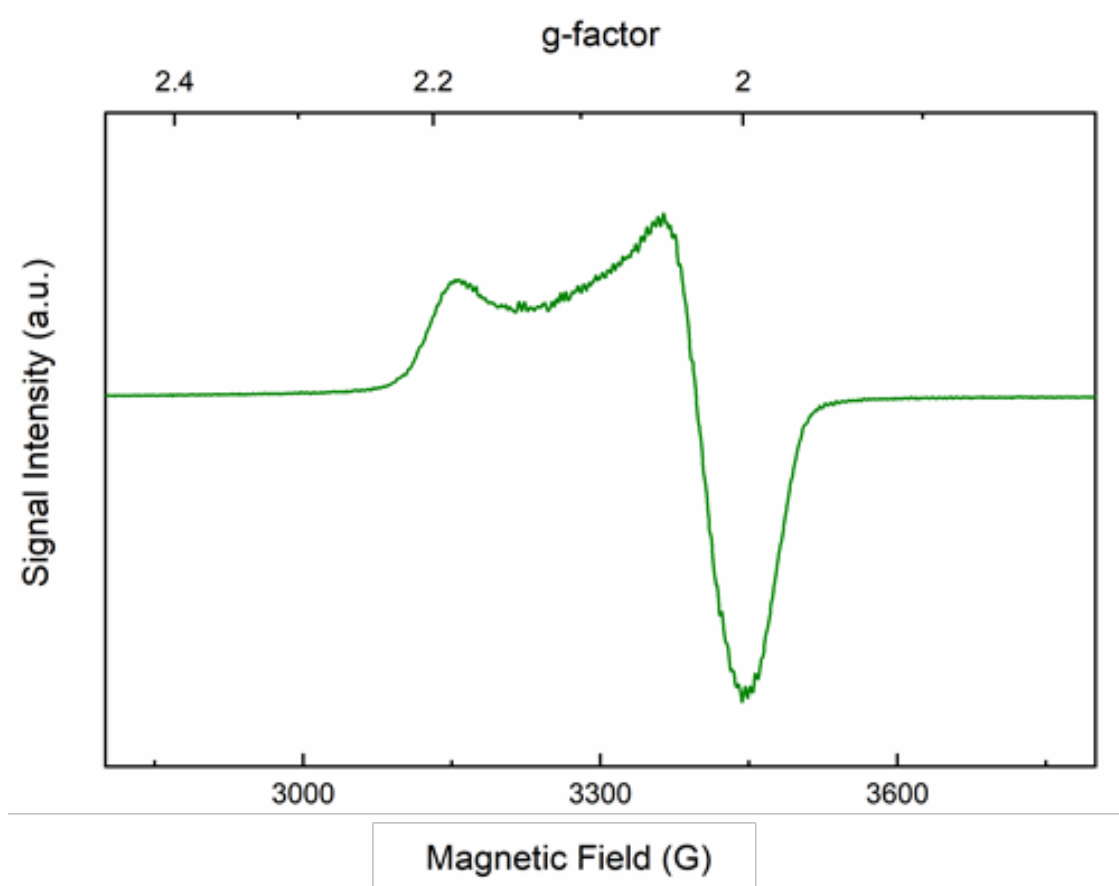

Figure 3. X-band EPR spectrum of isolated 3 in toluene $(T=8 \mathrm{~K}$, modulation amplitude $=4.0 \mathrm{G}$, time constant $=2.56 \mathrm{~ms})$. The spectrum shows axial symmetry $\left(\mathrm{g}_{1}=2.18, \mathrm{~g}_{2}=2.03\right)$, but no observable hyperfine coupling.

We next turned to interrogation of the reactivity of the [Cp*Rh $\mathrm{Ch}^{\mathrm{I}}$ complex 2 with a proton source in order to test for generation of a hydride complex..$^{[3,5,7,8,22]}$ Addition of a thawing acetonitrile solution of anilinium triflate $\left(\mathrm{p} K_{\mathrm{a}}=10.6\right.$ in $\left.\mathrm{CH}_{3} \mathrm{CN}^{[23]}\right)$ to a thawing THF solution of 2 results in lightening from dark red-brown to red-orange. Following extraction of the crude reaction mixture with THF, a $[\mathrm{Cp} * \mathrm{Rh}]$ monohydride formulated as $\left[\mathrm{Cp}^{*} \mathrm{Rh}(\mathrm{dppf}) \mathrm{H}\right]^{+}(\mathbf{4}$; see Scheme 1$)$ is left behind as a red-orange insoluble solid and can be isolated in pure form following further workup (see Experimental Section). The ${ }^{1} \mathrm{H}$ NMR of $\mathbf{4}$ exhibits a characteristic hydride signal consisting of a triplet of doublets $\left({ }^{1} J_{\mathrm{H}, \mathrm{Rh}}=18.7 \mathrm{~Hz}\right.$ and ${ }^{2} J_{\mathrm{H}, \mathrm{P}}=32.6 \mathrm{~Hz}$ ) centered at $-11.3 \mathrm{ppm}$ (see SI, Figure S7). Infrared spectroscopic data confirm the presence of a direct $\mathrm{Rh}-\mathrm{H}$ interaction, as suggested by a $\mathrm{Rh}-\mathrm{H}$ stretching frequency at $1995 \mathrm{~cm}^{-1}$. This value for the $\mathrm{Rh}-\mathrm{H}$ stretching frequency is quite similar to values of 1982 and $1936 \mathrm{~cm}^{-1}$ obtained for related monohydrides supported by bis(diphenylphosphino)methane and 4,5-bis(diphenylphosphino)-9,9dimethylxanthene that our group has recently reported. ${ }^{[24]}$

Vapor diffusion of diethyl ether into a concentrated acetonitrile solution of $\mathbf{4}$ afforded single crystals of the monohydride suitable for XRD analysis. On two separate occasions, structures of 4 were obtained (v23e and q61k) that displayed pseudo-orthorhombic symmetry; the final structure of $4(\mathbf{q 6 1 k})$ could be placed in the monoclinic space group $\mathrm{P} 2_{1} / \mathrm{c}$, however, in light of structural features elucidated during multiple refinement cycles (see SI, pp. S40-S41 for details). The $\mathrm{Rh}^{\mathrm{III}}$ center in 4 displays pseudo-octahedral geometry, consistent with generation of the proposed hydride; the hydride hydrogen atom H1A could be located from a difference Fourier and was included in the structural model of $\mathbf{4}$ as an independent isotropic atom whose parameters were allowed to vary in least-squares refinement cycles (see Figure 4). The data provide a reasonable estimated $\mathrm{Rh}-\mathrm{H}$ distance of $1.42(12) / 1.46(12) \AA^{[25]}$ with the caveat that the presence of the electron-rich rhodium could lead to underestimation of the Rh-H distance. ${ }^{[26]}$ As has been observed 
in prior structures of dppf bound to rhodium, ${ }^{[13,27]}$ the cyclopentadienyl rings within dppf were found to be canted slightly toward the $\mathrm{Rh}$ center in 4 , with $6.5^{\circ} / 3.0^{\circ}$ between their mean planes ${ }^{[25]}$ in the two molecular cations found in the unit cell of the structure of 4 .

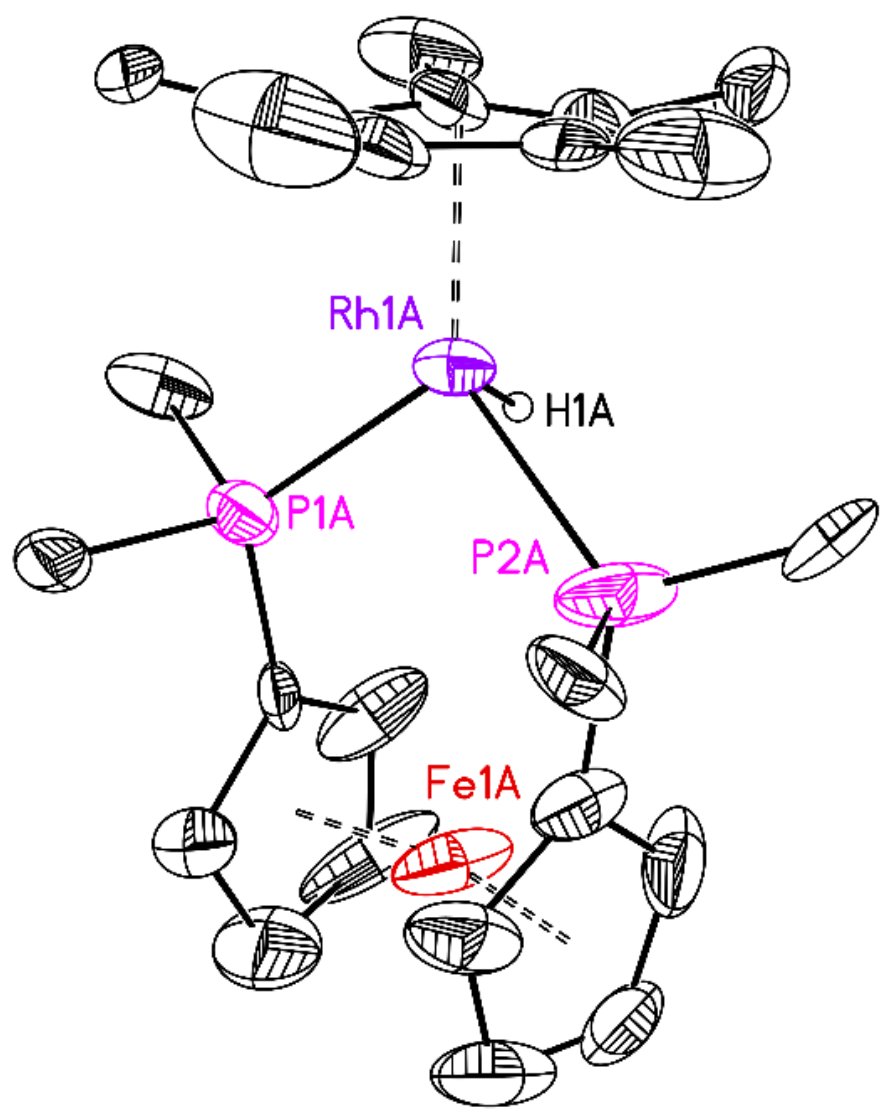

Figure 4. Molecular structure of 4 . The outer-sphere triflate counter-anion and all hydrogen atoms except H1A are omitted for clarity; terminal phenyl groups are also truncated for clarity as well. Thermal ellipsoids are shown at the 50\% probability level.

We have previously found that diphosphine-supported [Cp* Rh] monohydrides are not readily protonolyzed by the strong acid dimethylformamidinium (denoted $[\mathrm{DMFH}]^{+} ; \mathrm{p} K_{\mathrm{a}}=6.1$ in $\mathrm{MeCN}{ }^{[23]}$ ) when they are in the formal rhodium(III) oxidation state. Consequently, these compounds do not generate $\mathrm{H}_{2}$ under most conditions and generally appear to be rather inert. Despite the presence of the larger rhodacycle in $\mathbf{4}$ compared to the other available hydrides, ${ }^{[7,24]} \mathrm{we}$ find that addition of $[\mathrm{DMFH}]^{+}[\mathrm{OTf}]^{-}$does not lead to any detectable reactivity over $24 \mathrm{~h}$ as determined by ${ }^{1} \mathrm{H}$ NMR spectroscopy (see SI, Figure S10). Thus, in terms of chemical reactivity, 4 can be concluded to behave similarly to the other known diphosphine-supported [Cp*Rh] monohydrides. We note here that this conclusion applies to the formal oxidation level of isolated 4, which features rhodium(III) and iron(II) centers.

Next, we turned to electrochemical interrogation of the electron transfer behavior of $\mathbf{4}$ (see Figure 5). 4 is redox-inactive between ca. -0.9 and $0.1 \mathrm{~V}$ vs. $\mathrm{Fc}^{+/ 0}$ (Figure 5, upper set of voltammograms, black line). Upon scanning anodically to more positive potentials, however, 4 undergoes an electrochemically quasireversible oxidation centered at $+0.41 \mathrm{~V}$ vs. $\mathrm{Fc}^{+/ 0}$ with $\Delta E_{\mathrm{p}}=$ 
$137 \mathrm{mV}$ (Figure 5, blue line); we assign this process as the $\mathrm{Fe}^{\text {IIIIIII }}$ couple of the dppf ligand in 4 . Intriguingly, traversing this quasi-reversible $\mathrm{Fe}$-centered couple gives rise to a new cathodic feature with $E_{\mathrm{p}, \mathrm{c}}=-1.01 \mathrm{~V} \mathrm{vs.} \mathrm{Fc}^{+/ 0}$ (Figure 5, light blue line). Comparison of this data to those for 2 confirms this wave at $-1.01 \mathrm{~V}$ to correspond to reduction of the parent complex [Cp* $\left.\mathrm{Rh}^{\mathrm{II}}(\mathrm{dppf})\right]^{+}$ to $\mathrm{Cp}^{*} \mathrm{Rh}^{\mathrm{I}}(\mathrm{dppf})$, implying that oxidation of dppf in $\mathbf{4}$ stimulates loss of the hydride ligand and generation of $\left[\mathrm{Cp} * \mathrm{Rh}^{\mathrm{II}}(\mathrm{dppf})\right]^{+}$. Indeed, upon close inspection of the redox event at $+0.41 \mathrm{~V}$ in $\mathbf{4}$ at varying scan rates (see SI, Figure S31), a second anodic wave with $E_{\mathrm{p}, \mathrm{a}}=+0.54 \mathrm{~V}$ follows the initial oxidation at slower scan rates $(50-150 \mathrm{mV} / \mathrm{s})$. Similarly, at slower scan rates (e.g. $50 \mathrm{mV} / \mathrm{s}$ ) the coupled cathodic wave with $E_{\mathrm{p}, \mathrm{c}}=+0.36 \mathrm{~V}$ displays a shoulder at ca. $0.49 \mathrm{~V}$. These secondary anodic and cathodic waves compose a quasi-reversible process centered at $+0.51 \mathrm{~V}$ vs. $\mathrm{Fc}^{+/ 0}$ that is virtually identical to the midpoint potential of the $\mathrm{Fe}^{\mathrm{III/II}}$ couple in $2\left(E_{1 / 2}=+0.51 \mathrm{~V}\right)$. The second couple disappears as the scan rate is increased, however, suggesting that this species requires some time to form following electrochemical oxidation of $\mathbf{4}$. Taken together, these data suggest that following oxidation of $\mathbf{4}$, a chemical reaction occurs that generates $\left[\mathrm{Cp} * \mathrm{Rh}^{\mathrm{II}}(\mathrm{dppf})\right]^{+}$which can be oxidized to generate a $\mathrm{Rh}^{\mathrm{III}}$ species that is then present at the electrode surface to undergo oxidation of the dppf ligand at $+0.51 \mathrm{~V}$ vs. $\mathrm{Fc}^{+/ 0}$. Faster scan rates allow the electrochemical detection/interconversion of species near the electrode to eclipse the rate of this chemical process, giving rise to a single, chemically reversible $\mathrm{Fe}^{\mathrm{III} / \mathrm{II}}$ couple. The potential of this quasireversible event $(+0.41 \mathrm{~V})$ accessed at relatively fast scan rates provides the midpoint potential needed for use in thermochemical determinations (vide infra). 


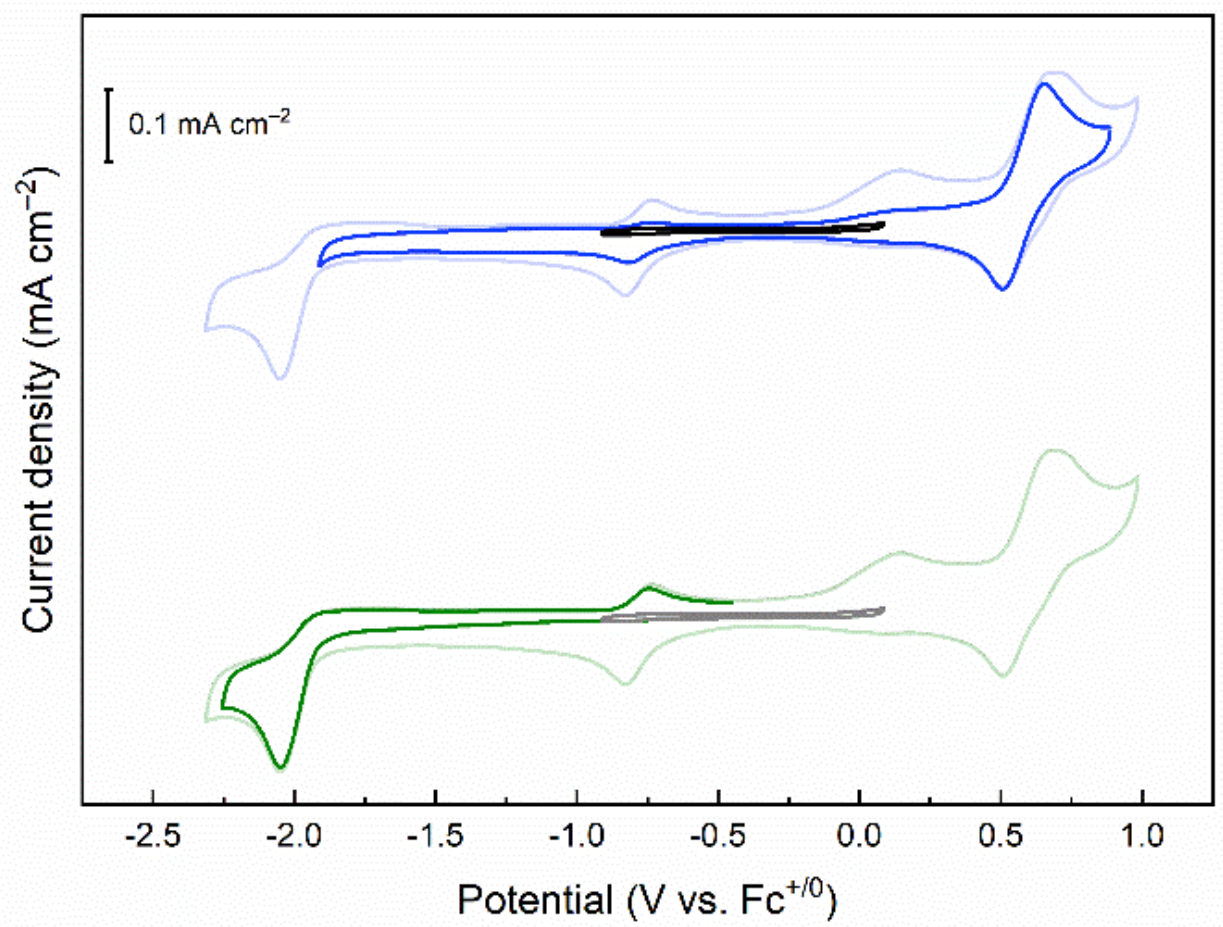

Figure 5. Cyclic voltammetry of $\mathbf{4}(2 \mathrm{mM})$ in THF. Upper Panel: Full CV of $\mathbf{4}$ (pale blue), CV of $\mathbf{4}$ from an initial potential of ca. $+1.0 \mathrm{~V}$ to $-1.85 \mathrm{~V}$ (blue), $\mathrm{CV}$ of $\mathbf{4}$ from an initial potential of ca. $0.1 \mathrm{~V}$ to $-0.9 \mathrm{~V}$ (black). Lower Panel: Full CV of $\mathbf{4}$ (pale green), $\mathrm{CV}$ of $\mathbf{4}$ from an initial potential of ca. $-0.50 \mathrm{~V}$ to $-2.25 \mathrm{~V}$ (green), $\mathrm{CV}$ of $\mathbf{4}$ from an initial potential of ca. $0.1 \mathrm{~V}$ to $-0.9 \mathrm{~V}$ (grey). Conditions: electrolyte, $0.1 \mathrm{M} \mathrm{TBAPF}_{6}$ in THF; scan rate, $100 \mathrm{mV} / \mathrm{s}$; working electrode, highly oriented pyrolytic graphite.

Turning to the reductive electrochemical properties of $\mathbf{4}$, voltammetry reveals an irreversible $1 \mathrm{e}^{-}$reduction with $E_{\mathrm{p}, \mathrm{c}}=-2.23 \mathrm{~V}$ (Figure 5, green line). Following up this reduction, two new anodic waves appear with $E_{\mathrm{p}, \mathrm{a}}=-0.91 \mathrm{~V}$ and $-0.01 \mathrm{~V}$ which are absent unless deep cathodic excursion to $-2.23 \mathrm{~V}$ is carried out. The noted return oxidation waves correspond to the potentials assigned as the $\mathrm{Rh}^{\mathrm{III}}$ and $\mathrm{Rh}^{\mathrm{II} / I I}$ processes previously measured with isolated $\mathrm{Cp} * \mathrm{Rh}(\mathrm{dppf})$ (2), respectively. This profile shows that the product of $1 \mathrm{e}^{-}$reduction of $\mathbf{4}$ reacts to form the $\mathrm{Rh}^{\mathrm{I}}$ species 2. Notably, the presence of the irreversible oxidation at $-0.01 \mathrm{~V} \mathrm{vs.} \mathrm{Fc}^{+/ 0}$ for in situ-generated 2 arising from reduction of $\mathbf{4}$ provides evidence that this feature corresponds to redox activity associated with $\mathbf{2}$. Reduction of 4 likely results in generation of a (formally) $\mathrm{Rh}^{\mathrm{II}}-\mathrm{H}$ complex; the reduction of $\mathbf{4}$ observed at $-2.23 \mathrm{~V}$ closely resembles a similar, chemically irreversible reduction wave measured with $[\mathrm{Cp} * \mathrm{Rh}(\mathrm{dppb}) \mathrm{H}]^{+}$in our prior work. Reduction of $[\mathrm{Cp} * \mathrm{Rh}(\mathrm{dppb}) \mathrm{H}]^{+}$resulted in $\mathrm{Rh}-\mathrm{H}$ bond cleavage and generation of $\mathrm{H}_{2}$ gas with high faradaic yield. ${ }^{[7]} \mathrm{A}$ similar process likely dominates the reductive chemistry of $\mathbf{4}$, on the basis of the similar potential and irreversible nature of the reductive wave for $\mathbf{4}$ in comparison with $[\mathrm{Cp} * \mathrm{Rh}(\mathrm{dppb}) \mathrm{H}]^{+}$. 
With the electrochemical characterizations of $1,2,3$, and 4 in hand, we next turned to quantification of the bond dissociation free energies (BDFE values) associated with cleavage of the $\mathrm{Rh}-\mathrm{H}$ moiety. This quantification was pursued in order to obtain the BDFE values of the isolated $\left[\mathrm{Fe}^{\mathrm{II}} \mathrm{Rh}^{\mathrm{III}}-\mathrm{H}\right]^{+}$form (4) as well as its oxidized analogue $\left[\mathrm{Fe}^{\mathrm{III}} \mathrm{Rh}^{\mathrm{III}}-\mathrm{H}\right]^{2+}$ that can be generated electrochemically. The $B D F E$ values were calculated using a set of three thermodynamic cycles as shown in Figure 6. ${ }^{[28,29,30]}$ The experimentally-determined reduction potentials are given in red; these were harvested from the electrochemical work described above. As $\mathbf{2}$ is insoluble in $\mathrm{CH}_{3} \mathrm{CN}$, a solvent more commonly used for thermochemical studies, the values reported here were obtained in THF. As a result, the $B D F E$ and $\mathrm{p} K_{\mathrm{a}}$ values reported here cannot be directly compared to those in $\mathrm{CH}_{3} \mathrm{CN}$.

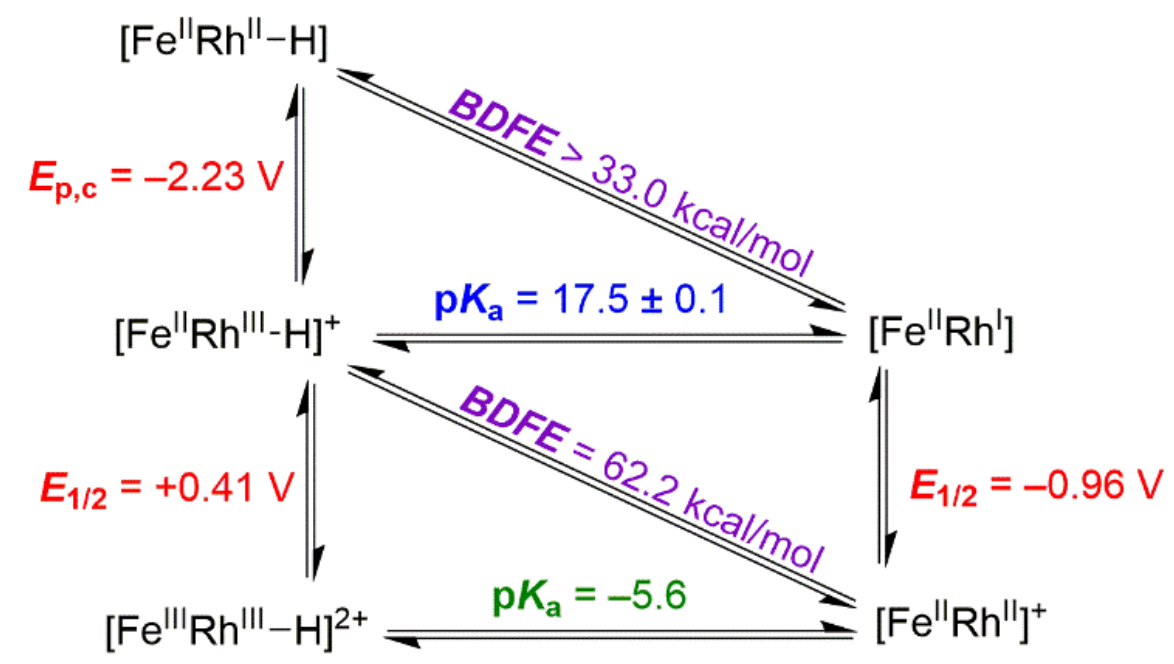

Figure 6. Thermochemical "square" scheme for the [Cp*Rh(dppf)] system.

A key experimental value needed to unlock the $B D F E$ values of the two oxidation states of the hydride is the $\mathrm{p} K_{\mathrm{a}}$ value of the isolated ( $\mathrm{Fe}^{\mathrm{II}}$ ) form of the hydride $\mathbf{4}$ (shown with blue text in Figure 6). The $\mathrm{p} K_{\mathrm{a}}$ associated with interconversion of $\mathbf{2}$ and $\mathbf{4}$ was determined by a titration of $\mathbf{4}$ with the addition of increasing volumes of neat triethylamine while monitoring with UV-visible spectroscopy (see SI, Equation S6 and Figure S24). Triethylamine was determined to be appropriate for this work based on the $\mathrm{p} K_{\mathrm{a}}$ value for $\mathrm{Et}_{3} \mathrm{~N} /\left[\mathrm{Et}_{3} \mathrm{NH}\right]^{+}$, which is 14.9 in THF. ${ }^{[31]}$ Analysis of the data revealed that the Rh-H moiety in 4 has a $\mathrm{p} K_{\mathrm{a}}$ of $17.5 \pm 0.1$, a value that compares well to the $\mathrm{p} K_{\mathrm{a}}$ values of other $\mathrm{Rh}^{\mathrm{III}}$ monohydrides that we have studied. On the other hand, the $\mathrm{Rh}-\mathrm{H}$ moiety in $\mathbf{4}$ is $100 \mathrm{x}$ as acidic as $[\mathrm{Cp} * \mathrm{Rh}(\mathrm{dppb}) \mathrm{H}]^{+}{ }^{[10]}$

With all these data in hand, the $B D F E$ values given in Table 1 and Figure 6 were determined. Using the established value of $60.4 \mathrm{kcal} \mathrm{mol}^{-1}$ as the $B D F E$ of $\mathrm{H}_{2}$ in THF as determined by Mayer and coworkers, ${ }^{[32]}$ the $B D F E$ of $\mathbf{4}$ was determined to be $62.2 \mathrm{kcal} \mathrm{mol}^{-1}$. This positive value, indicative of a strong $\mathrm{Rh}-\mathrm{H}$ interaction, is consistent with the general inertness of diphosphinesupported $[\mathrm{Cp} * \mathrm{Rh}]$ monohydrides to protonolysis.$^{[7,10,24]} \mathrm{As} 1 \mathrm{e}^{-}$reduction of $\mathbf{4}$ is fully irreversible even at relatively fast scan rates $(500 \mathrm{mV} / \mathrm{s})$, we were forced to rely on the cathodic peak reduction potential for determination of the $B D F E$ of the reduced form of $\mathbf{4}$ denoted as $\mathbf{5}$. The calculated $B D F E$ represents a lower bound, since the formal potential for interconversion of $\mathbf{4}$ and $\mathbf{5}$ must be more positive than the value of $E_{\mathrm{p}, \mathrm{c}}$ used here. As observed in the analogous hydride supported by 
$\mathrm{dppb},{ }^{[7]}$ metal-centered reduction of the $\left[\mathrm{Cp}^{*} \mathrm{Rh}^{\mathrm{III}}-\mathrm{H}\right]$ moiety is predicted to result in a substantial weakening of the $\mathrm{Rh}-\mathrm{H}$ bond; here, as in the dppb system, the BDFE decreases upon reduction by ca. $30 \mathrm{kcal} \mathrm{mol}^{-1}$. Consistent with the prediction that $\mathrm{H}_{2}$ generation via a homolytic mechanism becomes favorable upon reduction, bulk electrolysis studies revealed the faradaic efficiency of $\mathrm{H}_{2}$ generation upon reduction of 4 at $-2.1 \mathrm{~V}$ vs. $\mathrm{Fc}^{+/ 0}$ to be $>49 \%$, consistent with the expected yield of 50\% (see SI, Figure S32). ${ }^{[10]}$ Interrogation of the working chamber solution with UV-visible absorption spectroscopy following electrolysis confirmed generation of $\mathrm{Cp} * \mathrm{Rh}(\mathrm{dppf})$ (2) (see SI, Figure S25).

Table 1. Thermodynamic driving force for homolytic $\mathrm{H}_{2}$ evolution from the [Cp*Rh] monohydride $\mathbf{4}$ and its reduced form.

\begin{tabular}{|c|c|c|c|c|}
\hline $\begin{array}{l}\text { Speci } \\
\text { es }\end{array}$ & $\begin{array}{l}\text { Metal } \\
\text { Oxidation } \\
\text { States }\end{array}$ & $B D F E^{a}$ & $\underset{\substack{\Delta \mathbf{y t i}^{\mathrm{a}} \\
\mathbf{a}}}{\mathbf{a}}$ & $\begin{array}{l}\text { a } \Delta \mathrm{G}^{\mathrm{o}}{ }_{\mathrm{HER} \text {,homolytic }} \text { is the thermodynamic driving } \\
\text { force for } \mathrm{H}_{2} \text { evolution via a homolytic } \\
\text { pathway wherein the H-atoms in } \mathrm{H}_{2} \text { are }\end{array}$ \\
\hline 4 & {$\left[\mathrm{Fe}^{\mathrm{II}} \mathrm{Rh}^{\mathrm{III}}\right]^{+}$} & 62.2 & 20.5 & $\begin{array}{l}\text { derived from homolytic cleavage of two } \mathrm{Rh}- \\
\mathrm{H} \text { units. This quantity is discussed in detail }\end{array}$ \\
\hline 5 & {$\left[\mathrm{Fe}^{\mathrm{II}} \mathrm{Rh}^{\mathrm{II}}\right]$} & $\geq 33$ & $\geq-38$ & in reference 10 \\
\hline
\end{tabular}

Qualitatively, the thermodynamically-favorable reactivity pathways of 4 resemble those of the analogous [Cp*Rh] monohydride supported by the dppb ligand. ${ }^{[7]}$ However, the monohydride 4 is distinguished from its analogue supported by dppb in that it displays a quasi-reversible oxidation event at $+0.41 \mathrm{~V}$. Because of this accessible oxidation, the third thermodynamic cycle in the lower portion of Figure 6 could be completed and the $\mathrm{p} K_{\mathrm{a}}$ value of the oxidized hydride, formulated as $\left[\mathrm{Cp}^{*} \mathrm{Rh}(\mathrm{dppf}) \mathrm{H}\right]^{2+}$ with both the rhodium and iron centers present in the +III oxidation state (6). The $\mathrm{p} K_{\mathrm{a}}$ value of this species was calculated with the $E_{1 / 2}$ value for the dppf-centered redox and by rearrangement of the Bordwell Equation, as the BDFE value of $\mathbf{4}$ is known from the earlier calculations (vide supra). Consistent with the dicationic nature of $\mathbf{6}$, the predicted $\mathrm{p} K_{a}$ of the $\mathrm{Rh}-$ $\mathrm{H}$ shifts drastically upon oxidation by 23 orders of magnitude.

Experimental evidence for this shift was obtained through an in situ oxidation study with ${ }^{1} \mathrm{H}$ NMR monitoring. In the experiment, we hypothesized that the oxidized form $\mathbf{6}$ should be sufficiently acidic to protonate the weak Brønsted base dimethylformamide (DMF; $\mathrm{p} K_{\mathrm{a}}=6.1$ in $\mathrm{MeCN}^{[23]}$ ). Considering that the reduced species $\mathbf{4}$ is inert to protonolysis by the strong acid $[\mathrm{DMFH}]^{+}$(vide supra), the drastic predicted $\mathrm{p} K_{\mathrm{a}}$ shift corresponds to a significant swing in reactivity.

To carry out this test, 4 was mixed with 1 equiv. of the strong oxidant $\left[\mathrm{Ru}^{\mathrm{III}}(\mathrm{bpy})_{3}\right]\left(\mathrm{PF}_{6}\right)_{3}\left(E_{1 / 2}\right.$ $=+1.25 \mathrm{~V}$ vs NHE in $\mathrm{MeCN}^{[33,34]}$ ) as well as 1 equiv. of DMF in a J-Young NMR tube to check for the generation of $[\mathrm{DMFH}]^{+}$by ${ }^{1} \mathrm{H} \mathrm{NMR}$ in $d_{3}-\mathrm{MeCN}$. Compared to control spectra for the individual starting materials, significant spectral changes for the complete mixture confirmed reactivity upon mixing (see SI, Figures S14-S15). In the aromatic region, four new resonances appeared in the range of 8.60-7.30 ppm, integrating to 1:1:1:1 (see SI Figure S18); these correspond to diamagnetic $\left[\mathrm{Ru}^{\mathrm{II}}(\mathrm{bpy})_{3}\right]^{2+}$, generated by reduction of $\left[\mathrm{Ru} \mathrm{u}^{\mathrm{III}}(\mathrm{bpy})_{3}\right]^{3+}$ by $\mathrm{Rh}$ species. In the aliphatic region, two triplet resonances appeared at $1.10 \mathrm{ppm}$ and $1.18 \mathrm{ppm}$ in a $1: 1$ ratio; these triplets are attributable to the $\eta^{5}-\mathrm{Cp}^{*}$ moieties on two distinct [Cp* $\mathrm{Rh}$ ] products. On the basis of control spectra, however, the signal at $1.10 \mathrm{pm}$ corresponds to the starting monohydride 4 (see 
SI, Figures S7 and S15). Between 4-5 ppm, signals associated with dppf ligands corresponding to 4 as well as the second dppf-ligated species were observed. Most importantly, however, the sharp singlets at 7.92, 2.89 and $2.77 \mathrm{ppm}$ corresponding to free DMF disappeared upon mixing; a set of new broad singlets appeared at $12.15,3.13$, and $2.99 \mathrm{ppm}$ that integrate $1: 3: 3$, closely resembling isolated $[\mathrm{DMFH}]^{+}[\mathrm{OTf}]^{-}$(see SI, Figures $\mathrm{S} 11$ and S15).

Using the $\mathrm{CHD}_{2} \mathrm{CN}$ solvent residual as an internal standard, the overall stoichiometry of the oxidation-induced reactivity could be confirmed (see SI, Scheme S1 and Figure S17). The broad singlet at $12.15 \mathrm{ppm}$ corresponds to generation of ca. 0.5 equiv. of $\mathrm{DMFH}^{+}$upon oxidation; this $\mathrm{DMFH}^{+}$is in equilibrium with the 0.5 equiv. of $\mathrm{DMF}$ also present, contributing to the slight differences in the resonances for the mixture in comparison with pure $[\mathrm{DMFH}]^{+}[\mathrm{OTf}]^{-}$. The observed signals correspond to a weighted average of the acid/base; based on the detected shifts and the parent spectra of the species involved, a $61 \%$ yield of [DMFH] ${ }^{+}$can be calculated, a value that reproduces the measured integrations reasonably well. In the observed reactivity, protonation of $\mathrm{DMF}$ to $\mathrm{DMFH}^{+}$by 6 can be visualized to result in generation of a transient species formulated as $\mathrm{Fe}^{\mathrm{III}}, \mathrm{Rh}^{\mathrm{I}}$ or $\mathrm{Fe}^{\mathrm{II}}, \mathrm{Rh}^{\mathrm{II}}$ in nature; the final integrations confirm that this transient is oxidized by $\mathrm{Ru}^{\mathrm{III}}$, leading to generation of a second $\mathrm{Cp}^{*}$-containing species that can be assigned as a solvento $\mathrm{Fe}^{\mathrm{II}}, \mathrm{Rh}^{\mathrm{III}}$ complex. Taken together, this work shows that oxidation of $\mathbf{4}$ does result in a remarkable acidification of the $\mathrm{Rh}-\mathrm{H}$ moiety, enabling protonation of DMF to form the strong acid [DMFH] ${ }^{+}$.

\section{Discussion}

The reactivity profile and thermochemical properties of monohydride 4 reveal that the $\mathrm{Rh}-\mathrm{H}$ bond in this compound is inert to reaction with an exogenous proton source to generate $\mathrm{H}_{2}$. On the basis of prior findings from our group with other [Cp*Rh] monohydrides supported by diphosphine ligands, the presence of two phosphine ligands can be concluded to result in the resistance of the $\mathrm{Rh}-\mathrm{H}$ moiety to protonolysis ${ }^{[7,10,24]}$ Here, bis(diphenylphosphino)ferrocene was used, engendering a large rhodacycle size and $\mathrm{P} 1-\mathrm{Rh}-\mathrm{P} 2$ bond angle of $98.7(2)^{\circ} / 100.3(2)^{\circ} .{ }^{[25]}$ Related monohydrides developed in our group that are supported by bis(diphenylphosphino)methane (dppm) and 4,5bis(diphenylphosphino)-9,9-dimethylxanthene (Xantphos) have also displayed resistance to protonolysis, despite having narrower $\mathrm{P} 1-\mathrm{Rh}-\mathrm{P} 2$ angles of $73.0(1)^{\circ}$ and $98.0(1)^{\circ}$, respectively. So far, the binding geometry of bidentate phosphines used to support these monohydrides has not afforded marked changes in their reactivity; this motivates the search for new activation modes that could coax greater reactivity from these species.

Considering their intrinsic redox chemistry, we have previously found that [Cp* $\mathrm{Rh}]$ monohydrides display very negative metal-centered reduction potentials. Although we showed here that carrying out reduction of monohydride 4 results in $\mathrm{Rh}-\mathrm{H}$ cleavage and $\mathrm{H}_{2}$ generation, the potential required for this process is too negative $\left(E_{\mathrm{p}, \mathrm{c}}=-2.23 \mathrm{~V}\right)$ to be catalytically useful. Installation of the redox-active dppf ligand, however, engenders a new redox manifold and enables the facile electrochemical oxidation of $\mathbf{4}$ at the site of the ferrocenyl moiety present in the dppf backbone. Importantly, the thermochemical and reactivity work shows that oxidation of the dppfsupported monohydride results in significant acidification of the $\mathrm{Rh}-\mathrm{H}$ moiety. The observation of the generation of $\mathrm{DMFH}^{+}$, a strong acid in $\mathrm{MeCN}$ with a literature $\mathrm{p} K_{\mathrm{a}}$ value of 6.1 in $\mathrm{MeCN}$, is consistent with the predicted greater acidity $\left(\mathrm{p} K_{\mathrm{a}}=-5.6\right)$ of the oxidized form of the monohydride. Thus, the redox-active nature of dppf promotes new chemistry not accessible with the inert monohydride 4. Moreover, considering the clean reactivity observed here, promotion of 
other chemical processes for $\mathrm{M}-\mathrm{H}$ species such as homolytic or heterolytic bond cleavage could be attractive pursuits in future work.

One redox-active ligand framework relevant to such pursuits could be the cobaltocenederived analogue of dppf, namely bis-(diphenylphosphino)cobaltocenium (dppc). ${ }^{[35]}$ The ligand dppc is distinguished by a moderate and reversible $\mathrm{Co}^{\mathrm{III} / \mathrm{II}}$ reduction potential of ca. $-1.3 \mathrm{~V}$ vs $\mathrm{Fc}^{+/ 0}$ in $\mathrm{CH}_{2} \mathrm{Cl}_{2}$, contrasting with the oxidative $\mathrm{Fe}^{\mathrm{III} / \mathrm{II}}$ redox chemistry of dppf. One-electron dppccentered reduction of the putative monohydride, formulated as $[\mathrm{Cp} * \mathrm{Rh}(\mathrm{dppc}) \mathrm{H}]^{2+}$, would be predicted to occur at a more positive potential than reduction of the hydride-ligated rhodium center ${ }^{[7]}$ Depending on the precise potentials involved, the $B D F E$ of the $\mathrm{Rh}-\mathrm{H}$ could be weakened upon ligand-centered reduction, promoting $\mathrm{Rh}-\mathrm{H}$ cleavage. Such a situation could leave to catalytic $\mathrm{H}_{2}$ evolution at modest potentials, while also leveraging the efficient reactivity and facile synthesis of phosphine-ligated [Cp*Rh] species demonstrated by our work. More broadly, however, enabling new ligand-centered redox could also promote new reactivity with diiminesupported [Cp*Rh] complexes; such species are more promiscuous in their reactivity, as they can form $\left[\eta^{4}-\mathrm{Cp} * \mathrm{H}\right]$ species and serve as robust catalysts in several contexts. ${ }^{[10]}$

\section{Conclusion}

We find that protonation of $\mathrm{Cp}^{*} \mathrm{Rh}(\mathrm{dppf})$ results in formation of $\left[\mathrm{Cp}^{*} \mathrm{Rh}(\mathrm{dppf}) \mathrm{H}\right]^{+} \mathrm{OTf}^{-}(4)$ and that the $\mathrm{Rh}-\mathrm{H}$ bond in $\mathbf{4}$ is inert to protonolysis and $\mathrm{H}_{2}$ generation with the strong acid $[\mathrm{DMFH}]^{+}$. However, 4 undergoes both an irreversible $1 \mathrm{e}^{-}$reduction at $-2.23 \mathrm{~V}$ and a quasireversible oxidation at $+0.41 \mathrm{~V}$, redox events that result in formation of more reactive species in both cases. The Rh-centered reduction gives rise to a ca. $30 \mathrm{kcal} \mathrm{mol}^{-1}$ decrease in the $B D F E$ of the $\mathrm{Rh}-\mathrm{H}$ moiety in $\mathbf{4}$; bulk electrolysis of $\mathbf{4}$ confirms that reduction results in $\mathrm{H}_{2}$ evolution as predicted by thermochemical analysis. In addition, the reversibility of the Fe $\mathrm{F}^{\mathrm{II} / \mathrm{II}}$ couple in $\mathbf{4}$ provides access to accurate thermochemical predictions of the effect of ligand-centered oxidation in this system. We find that oxidation of dppf results in acidification of the $\mathrm{Rh}-\mathrm{H}$ moiety by 23 orders of magnitude, indicating that the oxidation state of the ligand has a dramatic effect on the electron density and reactivity at the Rh center. Based on these findings we anticipate that use of redox-active ligands could be a promising strategy for development of tunable redox chemistry with $[\mathrm{Cp} * \mathrm{Rh}]$ complexes.

\section{Experimental Section}

General Considerations. All manipulations were carried out in dry $\mathrm{N}_{2}$-filled gloveboxes (Vacuum Atmospheres Co., Hawthorne, CA) or under $\mathrm{N}_{2}$ atmosphere using standard Schlenk techniques unless otherwise noted. All solvents were of commercial grade and dried over activated alumina using a PPT Glass Contour (Nashua, NH) solvent purification system prior to use, and were stored over molecular sieves. All chemicals were from major commercial suppliers and used as received after extensive drying. $\left[\mathrm{Cp} * \mathrm{RhCl}_{2}\right]_{2}$ was prepared according to literature procedures. ${ }^{[36],[37]}$

Deuterated NMR solvents were purchased from Cambridge Isotope Laboratories; $\mathrm{CD}_{3} \mathrm{CN}$ was dried over molecular sieves and $\mathrm{C}_{6} \mathrm{D}_{6}$ was dried over sodium/benzophenone. ${ }^{1} \mathrm{H},{ }^{13} \mathrm{C}$, and ${ }^{19} \mathrm{~F} \mathrm{NMR}$ spectra were collected on 400 or $500 \mathrm{MHz}$ Bruker spectrometers and referenced to the residual protio-solvent signal ${ }^{[38]}$ in the case of ${ }^{1} \mathrm{H}$ and ${ }^{13} \mathrm{C}$. Heteronuclear NMR spectra were referenced to 
the appropriate external standard following the recommended scale based on ratios of absolute frequencies $(\Xi) \cdot{ }^{[39]}$ Chemical shifts $(\delta)$ are reported in units of ppm and coupling constants $(\mathrm{J})$ are reported in Hz. Electronic absorption spectra were collected with an Ocean Optics Flame spectrometer and 1-cm pathlength quartz cuvettes. Elemental analyses were performed by Midwest Microlab, Inc. (Indianapolis, IN).

CCDC 2123618 contain the supplementary crystallographic data for complex 4 . These data can be obtained free of charge via www.ccdc.cam.ac.uk/data_request/cif, or by emailing data_request@ccdc.cam.ac.uk, or by contacting The Cambridge Crystallographic Data Centre, 12 Union Road, Cambridge CB2 1EZ, UK; fax: +44 1223336033.

Electrochemistry. Electrochemical experiments were carried out in a nitrogen-filled glove box. 0.10 M tetra(n-butylammonium)hexafluorophosphate (Sigma-Aldrich; electrochemical grade) in THF served as the supporting electrolyte. Measurements were made with a Gamry Reference 600 Plus Potentiostat/Galvanostat using a standard three-electrode configuration. The working electrode was the basal plane of highly oriented pyrolytic graphite (HOPG) (GraphiteStore.com, Buffalo Grove, Ill.; surface area: $0.09 \mathrm{~cm}^{2}$ ), the counter electrode was a platinum wire (Kurt J. Lesker, Jefferson Hills, PA; 99.99\%, $0.5 \mathrm{~mm}$ diameter), and a silver wire immersed in electrolyte served as a pseudo-reference electrode ( $\mathrm{CH}$ Instruments). The reference was separated from the working solution by a Vycor frit (Bioanalytical Systems, Inc.). Ferrocene (Sigma Aldrich; twice-sublimed) was added to the electrolyte solution at the conclusion of each experiment $(\sim 1 \mathrm{mM})$; the midpoint potential of the ferrocenium/ferrocene couple (denoted as $\mathrm{Fc}^{+/ 0}$ ) served as an external standard for comparison of the recorded potentials. Concentrations of analyte for cyclic voltammetry were typically $2 \mathrm{mM}$.

Synthetic Procedures. Complex 1 was synthesized according to a procedure from the literature. ${ }^{[13]}$

Synthesis of 2. A suspension of 1 in tetrahydrofuran $(0.3 \mathrm{~g}, 0.3084 \mathrm{mmol}, 1$ equiv.) was stirred over sodium-mercury amalgam (1\% Na in $\mathrm{Hg} ; 0.0709 \mathrm{~g} \mathrm{Na}^{0}, 3.0840 \mathrm{mmol}, 10$ equiv.) and stirred for $24 \mathrm{~h}$, during which time the orange suspension became a dark orange solution. The mixture was filtered, and the volatiles removed in vacuo to yield the desired compound as an air-sensitive reddish-brown solid $(0.1468 \mathrm{~g}, 60.1 \%) .{ }^{1} \mathrm{H}$ NMR $\left(400 \mathrm{MHz}, \mathrm{C}_{6} \mathrm{D}_{6}\right) \delta 8.06$ (ddd, $J=8.5,6.6,3.1$ $\mathrm{Hz}, 9 \mathrm{H}), 7.20(\mathrm{t}, J=7.5 \mathrm{~Hz}, 10 \mathrm{H}), 7.10(\mathrm{t}, J=7.4 \mathrm{~Hz}, 6 \mathrm{H}), 4.24(\mathrm{q}, J=1.7 \mathrm{~Hz}, 4 \mathrm{H}), 3.84(\mathrm{t}, J=$ $1.8 \mathrm{~Hz}, 4 \mathrm{H}), 1.48(\mathrm{t}, J=1.8 \mathrm{~Hz}, 15 \mathrm{H}) \mathrm{ppm} .{ }^{13} \mathrm{C}\left\{{ }^{1} \mathrm{H}\right\} \mathrm{NMR}\left(400 \mathrm{MHz}, \mathrm{C}_{6} \mathrm{D}_{6}\right) \delta 139.80-139.51$ $(\mathrm{m}), 134.75(\mathrm{t}, J=7.3 \mathrm{~Hz}), 128.03(\mathrm{~s}), 126.90(\mathrm{t}, J=4.8 \mathrm{~Hz}), 96.90(\mathrm{q}, J=2.8 \mathrm{~Hz}), 83.21-82.68$ $(\mathrm{m}), 74.45(\mathrm{t}, J=5.4 \mathrm{~Hz}), 71.51(\mathrm{t}, J=3.5 \mathrm{~Hz}), 10.36(\mathrm{~s}) \mathrm{ppm} .{ }^{31} \mathrm{P}\left\{{ }^{1} \mathrm{H}\right\} \mathrm{NMR}\left(400 \mathrm{MHz}, \mathrm{C}_{6} \mathrm{D}_{6}\right) \delta$ $50.06(\mathrm{~d}, J=231.9 \mathrm{~Hz})$.

Synthesis of 3. To a suspension of 2 in THF $(0.015 \mathrm{~g}, 0.0189 \mathrm{mmol}, 1$ equiv.) was added a suspension of $\left[\mathrm{Cp}_{2}{ }_{2} \mathrm{Fe}\right]^{+}(0.0089 \mathrm{~g}, 0.0189 \mathrm{mmol}, 1$ equiv. $)$ in THF. The solution was stirred for 1.5 hours and pumped down to yield a green solid. 3 was isolated as a green solid by fractionation, wherein the hexanes-insoluble material was washed with $\mathrm{Et}_{2} \mathrm{O}$ and toluene and then extracted into THF. Removal of volatile solvent yielded a dark green solid $(0.083 \mathrm{~g}, 83 \%)$. Vapor diffusion of diethyl ether into a concentrated acetonitrile solution of the product yielded dark green crystals of 3 suitable for EPR analysis $\left(T=8 \mathrm{~K}\right.$, modulation amplitude $=4.0 \mathrm{G}$, time constant $=2.56 \mathrm{~ms}, \mathrm{~g}_{1}$ $=2.18, \mathrm{~g}_{2,3}=2.03$ ).

Synthesis of 4. To a suspension of 2 in thawing THF $(0.050 \mathrm{~g}, 0.0631 \mathrm{mmol}, 1$ equiv.) was added a suspension of thawing anilinium triflate $\left(0.0116 \mathrm{~g}, 0.0516 \mathrm{mmol}, 1\right.$ equiv.) in $\mathrm{CH}_{3} \mathrm{CN}$. 
The solution was stirred for 30 minutes and pumped down. Extraction of the crude reaction mixture with THF yielded an insoluble solid; dissolution of this solid in $\mathrm{CH}_{3} \mathrm{CN}$, followed by filtration and removal of volatiles in vacuo yielded the desired compound as a red-orange powder $(0.0395 \mathrm{~g}$, $66.6 \%$ ). Vapor diffusion of diethyl ether into a concentrated acetonitrile solution of the product yielded single-crystals of 4 suitable for X-ray diffraction studies. ${ }^{1} \mathrm{H}$ NMR $\left(400 \mathrm{MHz}, \mathrm{CD}_{3} \mathrm{CN}\right) \delta$ 7.90 (ddt, $J=9.6,5.9,2.2 \mathrm{~Hz}, 4 \mathrm{H}), 7.80-7.66(\mathrm{~m}, 10 \mathrm{H}), 7.57$ (dd, $J=4.5,2.6 \mathrm{~Hz}, 6 \mathrm{H}), 4.36$ (q, $J=1.8,1.4 \mathrm{~Hz}, 2 \mathrm{H}), 4.31(\mathrm{~d}, J=2.9 \mathrm{~Hz}, 2 \mathrm{H}), 4.26-4.20(\mathrm{~m}, 2 \mathrm{H}), 4.15(\mathrm{dq}, J=2.4,1.2 \mathrm{~Hz}, 2 \mathrm{H})$, $1.18(\mathrm{td}, J=3.0,1.2 \mathrm{~Hz}, 15 \mathrm{H}),-11.28(\mathrm{td}, J=32.5,18.6 \mathrm{~Hz}, 1 \mathrm{H}) \mathrm{ppm} .{ }^{13} \mathrm{C}\left\{{ }^{1} \mathrm{H}\right\} \mathrm{NMR}(400 \mathrm{MHz}$, $\left.\mathrm{CD}_{3} \mathrm{CN}\right) \delta 135.27(\mathrm{t}, J=6.3 \mathrm{~Hz}), 134.64-134.51(\mathrm{~m}), 132.45(\mathrm{~s}), 131.66(\mathrm{~s}), 103.67(\mathrm{~s}), 76.07$ $(\mathrm{t}), 74.61(\mathrm{t}), 73.99(\mathrm{t}), 73.74(\mathrm{t}, J=4.1 \mathrm{~Hz}), 8.89(\mathrm{~s}) \mathrm{ppm} .{ }^{31} \mathrm{P}\left\{{ }^{1} \mathrm{H}\right\}$ NMR $\left(400 \mathrm{MHz}, \mathrm{CD}_{3} \mathrm{CN}\right) \delta$ $46.42(\mathrm{~d}, J=149.8 \mathrm{~Hz}) \mathrm{ppm}$.

\section{Acknowledgements}

The authors thank Dr. Justin Douglas and Sarah Neuenswander for assistance with NMR and EPR spectroscopy. This work was supported by the US National Science Foundation through award OIA-1833087. Support for NMR and EPR instrumentation was provided by the US National Institutes of Health (S10OD016360 and S10RR024664) and by the US National Science Foundation (CHE-1625923).

Keywords: ligands $\bullet$ redox chemistry $\bullet$ hydrides $\bullet$ electrochemistry $\bullet$ crystallography 


\section{References}

[1] V. Lyaskovskyy and B. de Bruin, ACS Catalysis 2012, 2, 270-279.

[2] (a) P. J. Chirik and K. Wieghardt, Science 2010, 327, 794-795. (b) R. Eisenberg, Coord. Chem. Rev. 2011, 255, 825-836. (c) R. Eisenberg and H. B. Gray, Inorg. Chem. 2011, 50, 9741-9751. (d) R. Eisenberg, J. A. Ibers, R. J. H. Clark and H. B. Gray, J. Am. Chem. Soc. 1964, 86, 113-115. (e) ] J. H. Waters, R. Williams, H. B. Gray, G. N. Schrauzer and H. W. Finck, J. Am. Chem. Soc. 1964, 86, 4198-4199. (f) E. I. Stiefel, J. H. Waters, E. Billig and H. B. Gray, J. Am. Chem. Soc. 1965, 87, 3016-3017. (g) G. N. Schrauzer and V. Mayweg, J. Am. Chem. Soc. 1962, 84, 3221-3221. (h) G. N. Schrauzer and V. P. Mayweg, J. Am. Chem. Soc. 1965, 87, 3585-3592. (i) G. N. Schrauzer and V. P. Mayweg, J. Am. Chem. Soc. 1965, 87, 1483-1489.

[3] a) U. Kölle and M. Grätzel, Angew. Chem. 1987, 99, 572-574. b) U. Kölle and M. Grätzel Angew. Chem., Int. Ed. Engl. 1987, 26, 567-570.

[4] (a) R. Ruppert, S. Herrmann and E. Steckhan, Tetrahedron Letters 1987, 28, 6583-6586. (b)

R. Ruppert, S. Herrmann and E. Steckhan, J. Chem. Soc., Chem. Commun. 1988, 11501151. (c) E. Steckhan, S. Herrmann, R. Ruppert, E. Dietz, M. Frede and E. Spika, Organometallics 1991, 10, 1568-1577. (d) H. C. Lo, C. Leiva, O. Buriez, J. B. Kerr, M. M. Olmstead and R. H. Fish, Inorg. Chem. 2001, 40, 6705-6716. (e) P. M. Maitlis, Acc. Chem. Res. 1978, 11, 301-307. (f) A. Nutton, P. M. Bailey and P. M. Maitlis, J. Chem. Soc., Dalton Trans. 1981, 1997-2002.

[5] Y. Peng, M. V. Ramos-Garcés, D. Lionetti and J. D. Blakemore, Inorg. Chem. 2017, 56, 10824-10831.

[6] (a) L. M. A. Quintana, S. I. Johnson, S. L. Corona, W. Villatoro, W. A. Goddard, M. K. Takase, D. G. VanderVelde, J. R. Winkler, H. B. Gray and J. D. Blakemore, Proc. Nat. Acad. Sci. U.S.A. 2016, 113, 6409-6414. (b) W. C. Henke, D. Lionetti, W. N. G. Moore, J. A. Hopkins, V. W. Day and J. D. Blakemore, ChemSusChem 2017, 10, 4589-4598. (c) S. Pal, S. Kusumoto and K. Nozaki, Organometallics 2018, 37, 906-914. (d) S. Banerjee, J. J. Soldevila-Barreda, J. A. Wolny, C. A. Wootton, A. Habtemariam, I. Romero-Canelón, F. Chen, G. J. Clarkson, I. Prokes, L. Song, P. B. O'Connor, V. Schünemann and P. J. Sadler, Chem. Sci. 2018, 9, 3177-3185.

[7] E. A. Boyd, D. Lionetti, W. C. Henke, V. W. Day and J. D. Blakemore, Inorg. Chem. 2019, 58, 3606-3615.

[8] J. A. Hopkins, D. Lionetti, V. W. Day and J. D. Blakemore, Organometallics 2019, 38, 13001310.

[9] S. I. Johnson, H. B. Gray, J. D. Blakemore and W. A. Goddard, Inorg. Chem. 2017, 56, $11375-11386$.

[10] Lionetti, D., Hopkins Leseberg, J.A., Boyd, E.A., Peng, Y., Lassalle-Kaiser, B., and Blakemore, J.D. submitted for publication

[11] T. M. Miller, K. J. Ahmed and M. S. Wrighton, Inorg. Chem. 1989, 28, 2347-2355.

[12] C. A. Sassano and C. A. Mirkin, J. Am. Chem. Soc., 1995, 117, 11379-11380.

[13] J. F. Ma, Y. Yamamoto, J. Organomet. Chem. 1999, 574, 148-154.

[14] T. Sixt, J. Fiedler, W. Kaim, Inorg. Chem. Comm. 2000, 3, 80-82. 
[15] J.-M. Saveant, Elements of Molecular and Biomolecular Electrochemistry; Wiley: Hoboken, NJ, 2006.

[16] W. C. Henke, D. Lionetti, W. N. G. Moore, J. A. Hopkins, V. W. Day and J. D. Blakemore, ChemSusChem 2017, 10, 4589-4598.

[17] N. G. Connelly and W. E. Geiger, Chem. Rev. 1996, 96, 877-910.

[18] D. Lionetti, V. W. Day and J. D. Blakemore, Organometallics 2017, 36, 1897-1905.

[19] C. Elschenbroich, E. Bilger, R. D. Ernst, D. R. Wilson and M. S. Kralik, Organometallics 1985, 4, 2068-2071.

[20] K. Fuchigami, N. P. Rath and L. M. Mirica, Inorg. Chem. 2017, 56, 9404-9408.

[21] This is observed both for isolated samples of $\mathbf{2}$ and in electrochemical experiments that generate $\mathbf{2}$ in situ in the absence of chloride anions.

[22] J. A. Hopkins, D. Lionetti, V. W. Day and J. D. Blakemore, J. Organomet. Chem. 2020, 921, 121294.

[23] J. T. Muckerman, J. H. Skone, M. Ning and Y. Wasada-Tsutsui, Biochimica et Biophysica Acta (BBA) - Bioenergetics 2013, 1827, 882-891.

[24] C. G. Comadoll, W. C. Henke, J. A. Hopkins Leseberg, J. T. Douglas, A. G. Oliver, V. W. Day and J. D. Blakemore, Organometallics 2021, 40, 3808-3818.

[25] Two values are quoted for various structural properties of 4 because there are two unique molecular cations of the compound present in the unit cell of structure $\mathbf{q 6 1 k}$.

[26] M. Schmidtmann, P. Coster, P. F. Henry, V. P. Ting, M. T. Weller and C. C. Wilson, CrystEngComm 2014, 16, 1232-1236.

[27] (a) W. R. Cullen, T. J. Kim, F. W. B. Einstein and T. Jones, Organometallics 1985, 4, 346351. (b) B. Longato, G. Pilloni, R. Graziani and U. Casellato, J. Organomet. Chem. 1991, 407, 369-376. (c) Y. Yamamoto, H. Nakamura and J.-F. Ma, J. Organomet. Chem. 2001, 640, 10-20. (d) M. D. Jones, F. A. Almeida Paz, J. E. Davies and B. F. G. Johnson, Acta Cryst. E 2003, 59, m111-m113. (e) W. S. Han and S. W. Lee, Acta Cryst. C 2004, 60, m189m190. (f) C. Fischer, A. König, H.-J. Drexler and D. Heller, Z. Anorg. Allg. Chem. 2012, 638, 905-906. (g) F. Ye, J. Chen and T. Ritter, J. Am. Chem. Soc. 2017, 139, 7184-7187. (h) W. Clegg, CCDC 1575561: Experimental Crystal Structure Determination, CSD Communication 2017, doi: 10.5517/ccdc.csd.cc1pwhkm.

[28] F. G. Bordwell, Acc. Chem. Res. 1988, 21, 456-463.

[29] J. J. Warren, T. A. Tronic and J. M. Mayer, Chem. Rev. 2010, 110, 6961-7001.

[30] E. S. Wiedner, M. B. Chambers, C. L. Pitman, R. M. Bullock, A. J. M. Miller and A. M. Appel, Chem. Rev. 2016, 116, 8655-8692.

[31] E. P. Cappellani, S. D. Drouin, G. Jia, P. A. Maltby, R. H. Morris and C. T. Schweitzer, J. Am. Chem. Soc. 1994, 116, 3375-3388.

[32] C. F. Wise, R. G. Agarwal and J. M. Mayer, J. Am. Chem. Soc. 2020, 142, 10681-10691.

[33] R. E. DeSimone and R. S. Drago, J. Am. Chem. Soc. 1970, 92, 2343-2352.

[34] A. Juris, V. Balzani, F. Barigelletti, S. Campagna, P. Belser and A. von Zelewsky, Coord. Chem. Rev. 1988, 84, 85-277. 
[35] A. W. Rudie, D. W. Lichtenberg, M. L. Katcher and A. Davison, Inorg. Chem. 1978, 17, 2859-2863.

[36] White, C.; Yates, A.; Maitlis, P. M., (ๆ5-Pentamethylcyclopentadienyl)Rhodium and Iridium Compounds. Inorg. Synth. 1992, 29, 228-234.

[37] M. A. Mantell, J. W. Kampf and M. Sanford, Organometallics 2018, 37, 3240-3242.

[38] G. R. Fulmer, A. J. M. Miller, N. H. Sherden, H. E. Gottlieb, A. Nudelman, B. M. Stoltz, J. E. Bercaw and K. I. Goldberg, Organometallics 2010, 29, 2176-2179.

[39] (a) R. K. Harris, E. D. Becker, S. M. Cabral De Menezes, R. Goodfellow and P. Granger, Pure Appl. Chem. 2001, 73, 1795-1818. (b) R. K. Harris, E. D. Becker, S. M. Cabral De Menezes, P. Granger, R. E. Hoffman and K. W. Zilm, Pure Appl. Chem. 2008, 80, 59-84. 